\title{
Wheat blast: a new threat to food security
}

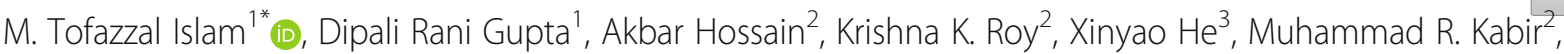 \\ Pawan K. Singh ${ }^{3}$, Md. Arifur Rahman Khan ${ }^{4}$, Mahfuzur Rahman ${ }^{5}$ and Guo-Liang Wang ${ }^{6}$
}

\begin{abstract}
Wheat blast, caused by the Magnaporthe oryzae Triticum (MoT) lineage (synonym Pyricularia oryzae Triticum lineage), is a destructive disease in South America and Bangladesh. It is primarily a disease of wheat head, which can cause yield loss up to $100 \%$ under favorable disease conditions. The head infection results in complete or partial bleaching of the spike above the point of infection with either no grain or shriveled grain with low test weight. Due to low fungicide efficacy against the disease and lack of availability of resistant varieties, an integrated management program should be adopted to control this serious wheat disease. First of all, a convenient and specific diagnostic tool is needed for evaluating seed health and early detection in wheat field to initiate timely mitigation measures and thereby decreasing pathogen initial inoculum and dispersal. Second, we should have a better understanding of the epidemiology of the disease and develop a real-time disease monitoring and surveillance system to alert growers to apply management practices at an optimum time. Third, we need a better understanding of the infection biology of the fungus and its interaction with wheat plants at the tissue and molecular levels helpful for improving disease management. Fourth, breeding for resistance to wheat blast can be accelerated by using resistance genes such as 2NS translocation, Rmg8 and RmgGR119 or advanced genomic technology such as CRISPR-Cas. Fifth, integration of alternative disease management practices, such as biological control using antagonistic microorganisms or derivatives thereof to achieve sustainable approach for the management of wheat blast. Finally, a globally concerted effort is needed using open science and open data sharing approaches to prevent this seed-and air-borne plant disease's widespread devastation of wheat crop. This comprehensive review updates our knowledge on wheat blast disease and discusses the approaches for its sustainable management for ensuring food and nutritional security of the ever-increasing global population.
\end{abstract}

Keywords: Genome evolution, Resistance genes, Biocontrol, Diagnostic tool, Gene editing

\section{Background}

The ever-increasing human population compels us to keep pace with the increasing global demand for food. Wheat is the third largest cereal species produced in the world after corn and rice (Food and Agricultural Organization, http://faostat.fao.org). It is the leading source of plant proteins in food for human consumption, as well as an important source of proteins for animal feed. Fungal disease outbreaks have affected plant productivity with increased frequency and are a recurrent threat to global food security (Fisher et al. 2012).

\footnotetext{
* Correspondence: tofazzalislam@gmail.com

${ }^{1}$ Institute of Biotechnology and Genetic Engineering (IBGE), Bangabandhu Sheikh Mujibur Rahman Agricultural University, Gazipur 1706, Bangladesh Full list of author information is available at the end of the article
}

One of the examples is wheat blast which is caused by the ascomycetous fungus Magnaporthe oryzae Triticum $(M o T)$ lineage (synonym Pyricularia oryzae Triticum lineage) (Igarashi et al. 1986; Islam et al. 2016). It has been considered as a serious threat to 3 million ha of wheat cultivated area in South America since its first emergence in Paraná state in Brazil in 1985 (Igarashi et al. 1986; Goulart et al. 1992, 2007; Kohli et al. 2011). In February 2016, wheat blast for the first time was spotted in Bangladesh (South Asia), a country outside of South America, and devastated more than 15,000 ha of wheat in eight districts of south-western and southern parts of Bangladesh (Callaway 2016; Islam et al. 2016; Malaker et al. 2016). The first epidemic of wheat blast in South Asia dramatically reduced the yield of wheat in

(c) The Author(s). 2020 Open Access This article is licensed under a Creative Commons Attribution 4.0 International License, which permits use, sharing, adaptation, distribution and reproduction in any medium or format, as long as you give appropriate credit to the original author(s) and the source, provide a link to the Creative Commons licence, and indicate if changes were made. The images or other third party material in this article are included in the article's Creative Commons licence, unless indicated otherwise in a credit line to the material. If material is not included in the article's Creative Commons licence and your intended use is not permitted by statutory regulation or exceeds the permitted use, you will need to obtain permission directly from the copyright holder. To view a copy of this licence, visit http://creativecommons.org/licenses/by/4.0/. 
the affected field up to $100 \%$. By the application of field pathogenomics and the open data sharing (www.wheatblast.net) approaches, the genetic identity and origin of the wheat blast pathogen were determined as a South American lineage of MoT (Callaway 2016; Islam et al. 2016). Later on, Ceresini et al. (2018) assumed that the wheat blast disease was introduced into Bangladesh through wheat grain trading from Brazil to Bangladesh.

Over the last 4 years, the fungus further spread to additional twelve new wheat-growing districts in Bangladesh, and thus it poses a new serious threat to future food and nutritional security of the country. Now, wheat blast is considered as a permanent disease of wheat in Bangladesh, though the major wheat-growing areas in the north-western part of the country is still free from this disease. This invasive fungus has raised a worldwide concern due to its potential spread to the neighboring wheat-growing regions in South Asia (Islam et al. 2019). About 124-million-ton wheat is produced in Indian sub-continent in 40.85 million ha. Climate analogue model suggested that 6.99 million ha wheat area is vulnerable to wheat blast and there may be a loss of worth 132 million USD considering 5\% blast-inflicted loss of wheat (Mottaleb et al. 2018). Neighboring India and China are the world's second and first largest wheat-producing countries, respectively, and the spread of this serious pathogen in those countries will be catastrophic.

The blast fungus has high levels of host-specificity and several lineages exist within this pathogen (Urashima et al. 1993; Kato et al. 2000; Gladieux et al. 2018). For example, the Oryza lineage $(\mathrm{MoO})$ infects rice and $M o T$ infects wheat and a few other members of Poaceae (Urashima et al. 1999; Tosa et al. 2006; Gladieux et al. 2018; Valent et al. 2019). The $M o O$ isolates are genetically distinct from wheat-infecting ones and generally do not infect wheat (Prabhu et al. 1992; Urashima et al. 1993; Urashima et al. 1999; Farman 2002; Faivre-Rampant et al. 2008; Tufan et al. 2009; Maciel et al. 2014; Chiapello et al. 2015; Yoshida et al. 2016). But MoT can infect triticale ( $\times$ Triticosecale), barley (Hordeum sativum) (Urashima et al. 2004), durum wheat, oat and some other weed species (Urashima et al. 1993). Typical symptoms of wheat blast on spikes are premature bleaching of spikelets and entire heads (Igarashi 1990; Urashima 2010). Severely affected wheat heads can be killed, resulting in severe yield losses (Igarashi 1990; Urashima 2010). The disease is generally spread by infected seeds and secondary infection occurs through air-borne spores, and the fungus can survive in infected crop residues and seeds (Urashima et al. 1999; Pizolotto et al. 2019).

Although some diagnostic protocols have been developed for the wheat blast, they are not highly convenient and unequivocally reliable (Pieck et al. 2017; Gupta et al. 2019). Therefore, a more convenient, rapid and costeffective diagnostic tool needs to be developed for surveillance and monitoring of this wheat pathogen. Fungicide sprays seem unreliable to control head blast after the expression of disease symptoms (McGrath 2001; Fernández-Ortuño et al. 2006; Castroagudin et al. 2015). The classical breeding for developing resistant wheat is limited by the few effective wheat blast resistant genes identified so far, including 2NS translocation, $R m g 8$ and RmgGR119, of which the first has been gradually eroded by new MoT virulence groups (Cruz et al. 2016b; Anh et al. 2015, 2018; Ceresini et al. 2018; Wang et al. 2018). In fact, this extreme virulence diversity explains why resistance has not been durable in Brazil. Introgression of the newly discovered $R m g 8$ and RmgGR119 genes, after confirming their effects in field experiments, to the commercial cultivar of wheat is a long term but could be a realistic plan for the development of blast resistant wheat in Bangladesh and South America. Although wheat blast has been a threat to successful wheat production in South America since 1985, the biology of the pathogen remains poorly understood. Therefore, novel molecular and plant breeding approaches are needed to address this emerging threat to food security.

During the last few decades, it has been apparent that there are genes in rice that are important for susceptibility to rice blast. When these genes are mutated, they lead to increased resistance to the disease (Zaidi et al. 2018; Kim et al. 2019). Therefore, identifying these orthologous genes in wheat and then generating their mutations by CRISPR-Cas technology may confer enhanced resistance to wheat blast (Zaidi et al. 2018; Kim et al. 2019). CRISPR-Cas is a revolutionary technique for genome editing which has already been used in disease resistance in several plants (Wang et al. 2016; Scheben and Edwards 2017; Haque et al. 2018; Islam 2019). Therefore, resistant wheat lines with edited $S$ genes could be developed using the latest CRISPR-Cas9 genome editing technology.

Alternatively, some plant-associated beneficial microorganisms are known to be effective to control rice blast disease (Park et al. 2005; Singh et al. 2012; Oliveira et al. 2015). These biocontrol agents may be worth testing for the management of wheat blast. Discovery of novel antagonistic plant probiotic (beneficial bacteria associated with plant) bacteria from the local environment including wheat and their metabolites could be an alternative option to less-effective fungicides for the management of the wheat blast (Surovy et al. 2017; Dutta et al. 2018; Chakraborty et al. 2020).

A good number of reviews have recently been published on various aspects of wheat blast disease (Cruz 
and Valent 2017; Ceresini et al. 2018, 2019; Vales et al. 2018; Islam et al. 2019). This comprehensive review updates our current knowledge and progresses of the mitigation of wheat blast using various novel approaches.

\section{Disease symptoms, and diagnostic tools for monitoring and surveillance of wheat blast in the field}

Accurate early detection of the pathogen in the field sample is the best strategy for the management of disease before it becomes epidemic. Diagnosis of wheat blast disease in the field at heading stage is difficult because it produces similar symptoms as those associated with Fusarium head blight (FHB) (Pieck et al. 2017). First visible symptom on the leaf is water-soaked and diamond-shaped lesions which turn into eye-shaped gray lesions with disease progression (Fig. 1). The eye-shaped lesions enlarge and coalesce with other lesions to kill the entire leaf. The most distinguishable symptom is observed in the head, which becomes partially or fully bleached. Complete or partial bleaching of the head above the point of infection with either no grain or shriveled grain with low test weight and poor nutrients is commonly observed (Goulart et al. 2007; Islam et al. 2016; Surovy et al. 2020) (Fig. 1). Infection at early stage of flowering results in sterility, and empty grains (Goulart et al. 1990; Goulart and Paiva 1992; Urashima et al. 2009). Multiple points of infection in the rachis can be observed and typically spread upward from its node. Whereas, infection at the grain filling stage results in small, shriveled, light, and discolored (pale) grains (Islam et al. 2016) and the affected grains are unfit for human consumption (Urashima et al. 2009; Surovy et al. 2020). Bleached heads have traces of gray, indicative of fungal sporulation at the point of infection (Islam et al. 2016). The white patchy symptoms at the reproductive stage are visible from a reasonable distance from the field.

Due to its high sensitivity and excellent specificity, molecular diagnosis has shown great application potential for many plant diseases pertaining to control and prevention of these diseases. In the case of blast disease, the Pot2 transposable elements, MGR583 and MoTeR are useful for the detection of $M$. oryzae, but it cannot distinguish the lineages of $M$. oryzae (Farman 2002; Pieck et al. 2017). To specifically identify a MoT lineage, Pieck et al. (2017) used a genome-based approach to find unique molecular markers for the detection of $M o T$ isolates. One of the markers, MoT3, which is derived from a retinol dehydrogenase gene was selected by analyzing $258 \mathrm{M}$. oryzae isolates from different hosts. This primer could amplify a 361-bp PCR product from all of the $M o T$ isolates but not from other M. oryzae isolates. Based on Pot2 and MoT3, Yasuhara-Bell et al. (2018) developed loop-mediated isothermal amplification (LAMP) assays for the specific detection of $M o T$ in lab and field
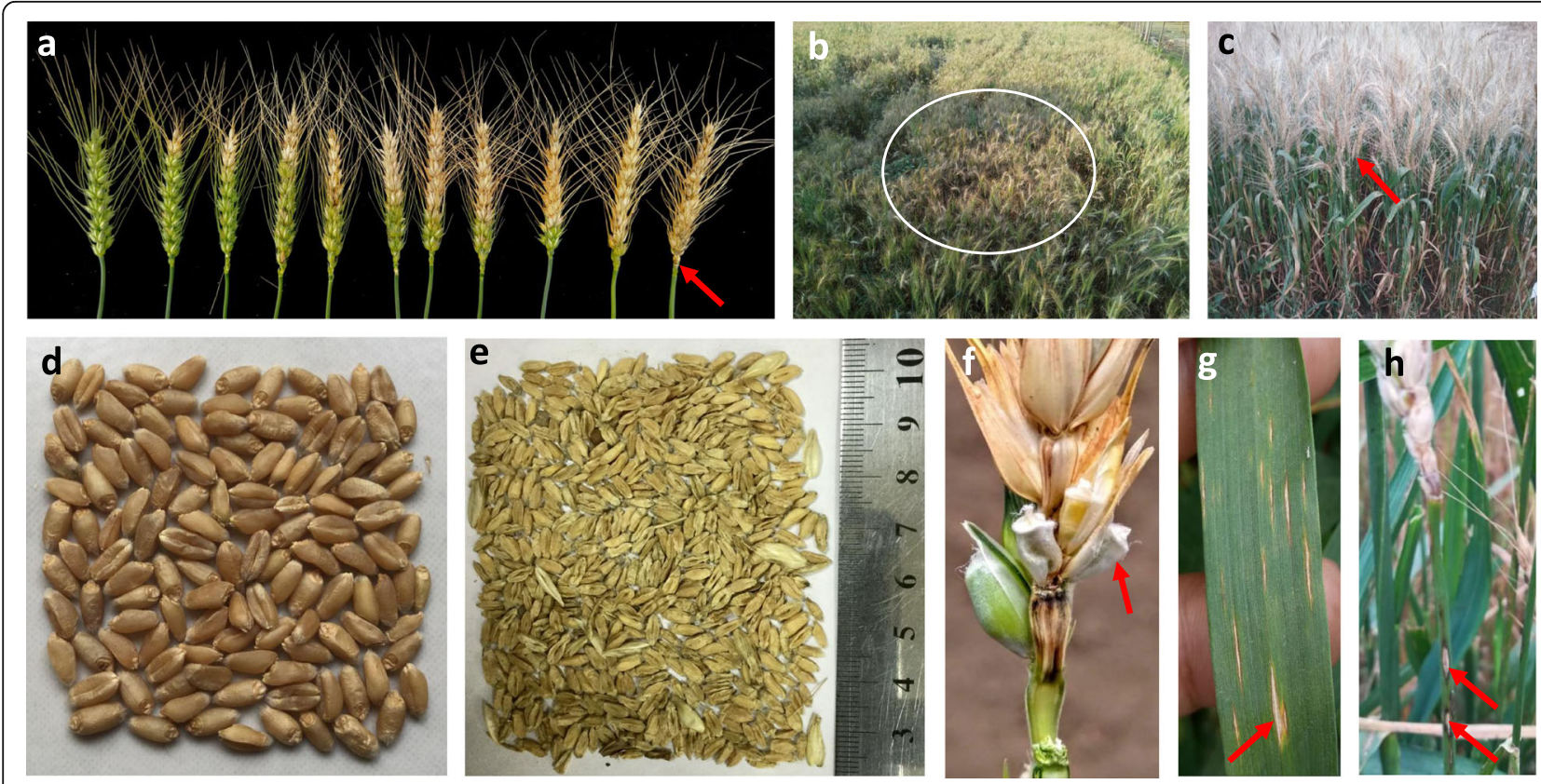

Fig. 1 Symptoms of blast disease in different parts of wheat plants. a Complete to partial infections (right to left) in wheat spikes collected from a blast-affected field. Arrow indicates the point of infection. $\mathbf{b}$ A characteristic patch (see the circle) of blast infection indicating the early stage of field infection. c Complete bleaching (arrow) of 100\% spikes in a blast-devastated field. d Unaffected and normal color of wheat grains. e Severely shrivelled or wrinkled and discoloured wheat grains affected by the wheat blast. $\mathbf{f}$ Two shrivelled grains (whitish color, arrow) and a normal (green)-colored unaffected grain just below the infection point in a spike. $\mathbf{g}$ Typical eye-shaped lesion (arrow) with gray center. $\mathbf{h}$ Brown colored lesions with gray centers (arrows) of an infected stem of wheat 
samples. This method may be useful in detecting trapped $M o T$ spores from the aerosol samples and for the prediction of epidemics along the year. However, Gupta et al. (2019) published a result contradictory to the previous result of Pieck et al. (2017) as they observed that under certain conditions, MoT3 primers also amplify both rice and wheat blast isolates. The assay is based on primers matching the WB12 sequence corresponding to a fragment of the M. oryzae MGG_02337 gene that is annotated as a short chain dehydrogenase and is present in both rice and wheat infecting $M$ oryzae isolates. Specifically, all eight rice blast isolates tested in this study produced the WB12 amplicon. In addition, comparative genomics of the WB12 nucleotide sequence revealed a complex underlying genetic structure with related sequences across $M$. oryzae strains and in both rice and wheat blast isolates. Recently, Thierry et al. (2020) identified unique polymorphisms in the Triticum lineage by analyzing 81 Magnaporthe genomes and developed C17, a real-time PCR-based detection method with high sensitivity. But it is still not clear whether this method is useful for detecting the pathogen in field samples and seed lot as no validation using real samples was done. Therefore, development of a convenient, cost-effective and rapid detection method of wheat blast disease in early stage of infection, in alternate hosts, and seed lot is urgently needed. With the support from the Coordinated Research Program of the International Atomic Energy Agency (IAEA), we aimed to develop an accurate and sensitive method to detect $M o T$ in the field. From the genome sequences of two MoT isolates from Brazil, we identified two DNA fragments that are present in the $M o T$ genome but not in the genome of $M o O$. Using PCR, we confirmed the specificity of the two markers in $53 \mathrm{MoT}$ and $\mathrm{MoO}$ isolates from South America and Bangladesh. Furthermore, we combined targetdependent Cas12a ssDNase activation with recombinase polymerase amplification (RPA) and nucleic acid lateral flow immunoassay (NALFIA) and developed a method that accurately, sensitively, and cost-effectively detects $M o T$-specific DNA sequences in infected wheat plants (Wang et al. unpublished). This novel technique should be easily adapted for rapid detection of wheat blast and other important plant diseases in the field.

\section{Geographical distribution and epidemiology of $M o T$ in different environments}

$M o T$ was first observed in the Paraná state of Brazil in 1985, then it gradually spread to other neighboring countries viz. Bolivia (1996), Paraguay (2002), and Argentina (2007). Now it is considered a potential threat to wheat production in about 3 million ha of wheatgrowing areas in South America. Currently, the worst affected regions include central and southern Brazil, the lowland Santa Cruz region of Bolivia, southern and south-eastern Paraguay and north-eastern Argentina (Kohli et al. 2011). Yield losses incurred as a result of infection have been estimated to range from 10 to $100 \%$ (Goulart and Paiva 2000; Goulart et al. 2007; Urashima et al. 2009; Duveiller et al. 2011). Although the origin of Brazilian wheat blast is still a debating issue, Inoue et al. (2017) demonstrated that it moved to wheat likely from a native grass through 'host jump'. In February of 2016, wheat blast was first reported in Bangladesh which was thought to be introduced from South America through grain trading (Islam et al. 2016; Ceresini et al. 2018). The genetic identity and origin of the isolates were determined by a large group of scientists from Asia, Europe, USA, Brazil and Australia using field pathogenomics and whole genome sequencing (Islam et al. 2016; Malaker et al. 2016). The field pathogenomics is a new method to analyze fungal disease from field samples and pinpoint the exact genotype in a faster way. Furthermore, this method is useful in sharing nucleic acid sequence data of the diseased materials (non-living) to the collaborating lab in other country in the case of a quarantined pest, such as wheat blast in Bangladesh. On the other hand, the successful application of open data sharing and open science which has been practiced in determining the origin of wheat blast in Bangladesh within weeks by the engagement of global scientific community seems a plausible smart strategy for tackling any plant health emergencies (Kamoun et al. 2019). Wheat blastlike symptoms in a single spike of wheat were also detected in an experimental field in Kentucky, USA in 2011 (Farman et al. 2017). In fact, the US wheat blast was likely caused by the 'host jump' of M. oryzae Lolium lineage from a native Lolium species (Inoue et al. 2017; Maekawa and Schulze-Lefert 2017).

In last 4 years, wheat blast spread to additional 12 new districts in Bangladesh aggravating the disease situation (Tables 1 and 2). Although no scientific report was published on the occurrence of the disease, the Indian government had banned wheat cultivation ('wheat holiday') in the areas adjacent to the border with Bangladesh where disease incidence was reported, $(\sim 2200 \mathrm{~km})$ and restricted the movement of wheat grains from the vulnerable areas to the inland of India (https://www.hindustantimes.com/kolkata/tackling-wheat-blast-bengal-government-bans-wheatcultivation-within-5-km-of-b-desh-border/story-QTVW ssXeR6BYNSNKh873IJ.html). It seems a timely strategy to decrease the inoculum build up and subsequent spread to a larger geographic region relevant to wheat cultivation. However, this strategy should also consider a concerted effort to find and destroy any alternative host where blast fungus may have established in a contaminated area. Several alternative/collateral hosts of this fungus have been reported. With the help of international collaborators, 
Table 1 Distribution of wheat blast disease across the world

\begin{tabular}{|c|c|c|c|c|c|c|c|}
\hline $\begin{array}{l}\text { Continent/ } \\
\text { Country/ } \\
\text { Region } \\
\end{array}$ & Distribution & $\begin{array}{l}\text { Last } \\
\text { reported }\end{array}$ & Origin & $\begin{array}{l}\text { First } \\
\text { reported }\end{array}$ & Invasive & Reference & Notes \\
\hline \multicolumn{8}{|l|}{ Asia } \\
\hline Bangladesh & Present: widespread & 2020 & Introduced & 2016 & Yes & $\begin{array}{l}\text { Islam et al. (2016); } \\
\text { Malaker et al. (2016) }\end{array}$ & $\begin{array}{l}\text { First recorded in the district of } \\
\text { Kushtia, Meherpur, Chuadanga, } \\
\text { Pabna, Jessore, Jhenaidah, Bhola } \\
\text { and Barisal }\end{array}$ \\
\hline \multicolumn{8}{|l|}{ North America } \\
\hline USA & $\begin{array}{l}\text { Infection occurred in only } \\
\text { one spike in an experimental } \\
\text { farm in Kentucky, USA which } \\
\text { was successfully contained. }\end{array}$ & - & $\begin{array}{l}\text { Host shift from } \\
\text { Lolium }\end{array}$ & 2011 & No & Farman et al. (2017) & $\begin{array}{l}\text { A gray leaf spot on annual \& } \\
\text { perennial ryegrass caused by } \\
\text { wheat blast pathogen was } \\
\text { recorded in } 1970 \text { and } 1992 \text {. }\end{array}$ \\
\hline \multicolumn{8}{|l|}{ South America } \\
\hline Brazil & Present: widespread & 2020 & $\begin{array}{l}\text { Host shift from } \\
\text { a local host }\end{array}$ & 1985 & Yes & Igarashi et al. (1986) & Paraná \\
\hline Bolivia & Present: widespread & 2020 & Introduced & 1996 & Yes & $\begin{array}{l}\text { Barea and Toledo } \\
\text { (1996) }\end{array}$ & Santa Cruz \\
\hline Paraguay & Present: widespread & 2020 & Introduced & 2002 & Yes & $\begin{array}{l}\text { Viedma and Morel } \\
\text { (2002) }\end{array}$ & $\begin{array}{l}\text { Alto Parana, Itapua, Caaguazu, } \\
\text { Caazapa, Canindeyu and Guaira }\end{array}$ \\
\hline Argentina & Present: widespread & 2020 & Introduced & 2007 & Yes & $\begin{array}{l}\text { Cabrera and } \\
\text { Gutiérres (2007) }\end{array}$ & Chaco and Corrientes \\
\hline
\end{tabular}

government of Bangladesh promptly responded to the first epidemic of wheat blast by taking a series of measures that include discouraging wheat cultivation in blast-affected areas for consecutive 3 years, seed production in blast-free areas, stopping use of wheat seed from infected areas, stopping seed production of susceptible varieties, regional workshops and training for awareness building, development of short-term management technologies and fast-track release of a moderately resistant variety (BARI Gom 33). Combination of these measures were found effective in containing the spread of wheat blast. Due to the seed- and air-borne mode of spread of the fungus, there is a high potential of its further spread to major wheat-growing areas in Asia where conditions remain most favorable for its infection during the wheat growing season and beyond. Several lines of evidence suggest that weather conditions in the USA, in some Asian and African countries are very suitable for wheat blast epidemics (Duveiller et al. 2011; Cruz et al. 2016a). Therefore, there is a high risk related to inadvertent introduction of this disease into those areas and devastation to follow. In 2011, Duveiller and co-workers reported that there are wheat-producing regions in the world where the disease has not been reported so far, but their climatic conditions are very similar to regions in South America where the disease frequently occurs. Furthermore, there is a risk of 'host shift' of this fungus from Lolium as this lineage is distributed worldwide including Europe. Table 1 summarizes the origin and distribution of wheat blast disease worldwide.

\section{Conducive weather for wheat blast}

Wheat blast is particularly a destructive disease as the disease progression is very rapid, leaving the farmer very little time to take preventive measures. Weather conditions are very critical factors for the development of wheat blast. Rainy and humid weather conditions during heading stage of wheat crop have been found to enhance the occurrence and development of wheat blast disease. Head blast severity greatly varies upon certain factors such as environmental conditions, cultivar susceptibility, and plant organ infected (Goulart et al. 2007; Urashima et al. 2009). The most vulnerable growth stage in terms of yield reduction is between anthesis and early grain development (Igarashi 1990). The combination of several factors such as higher temperature, rainfall during flowering stage, leaf/spike wetness has favoured the outbreak of the disease (Goulart et al. 2007; Islam et al. 2019). The most severe field infections occur in seasons when there are continuous rainfalls during the period of anthesis, with an average temperature of $18-25^{\circ} \mathrm{C}$, followed by a period of sunny, hot and humid weather (Kohli et al. 2011). In another study, Cardoso et al. (2008) reported that an optimum temperature ranging between 25 and $30^{\circ} \mathrm{C}$ and spike under wetness for 25$40 \mathrm{~h}$ can lead to a severe outbreak of the disease. Some blast researchers and wheat growers have reported the presence of initial hotspots within wheat fields that may lead to blast epidemic in Bolivia and Bangladesh. In addition, $M o T$ sporulation from a very low level of initial inoculum prior to spike initiation may supply enough 
secondary inoculum, which ultimately results in head blast epidemics (Cruz et al. 2015). Several reports predicted a temperature rise in Bangladesh, especially during winter season (Hossain and da Silva 2013), which may increase the risk of wheat blast. Another disease conducive environmmental factor might be heavy dew fall in winter in Bangladesh under which extra moisture retained for 16-17 $\mathrm{h}$ on wheat plant supporting fungal sporulation. In South America, severe epidemics occurred in the humid and warmer regions like Bolivia, Paraguay and northeastern Argentina (Kohli et al. 2011). Analysis of weather data collected from the Bangladesh Meteorological Department shows that the temperature rise occurred in all the regions in 2016 mainly due to a $1.8-6.5^{\circ} \mathrm{C}$ increase in minimum temperature compared to 2011-2015 (Islam et al. 2019). Such warming up coupled with rainfall at the flowering time likely contributed to the development of epidemic in the wheat blast-affected districts in 2016 in Bangladesh. The comparative status of blast incidence in Bangladesh with weather situation and other information are presented in Table 2 .

\section{Infection biology of MoT and its interactions with wheat plants}

The $M o T$ isolates can infect all aboveground parts of wheat plant. However, the infection process of MoT fungus on wheat leaves and spikes is still not well understood. Some recent results obtained by using scanning electron microscopy, laser confocal and bright field microscopy helped us to understand the infection mechanism to some extent (Ha et al. 2012). The infection cycle of the Magnaporthe fungus starts when the three-celled conidia attach to the plant surface. After that, conidia germinate to form polarized germ tubes from either one or both ends after $6 \mathrm{~h}$ of inoculation. Recognition of environmental cues such as surface hydrophobicity and toughness induces swelling at the tip of the germ tube, which then differentiates into the specialized infection structure called appressorium (Hamer et al. 1988; Tufan et al. 2009). The appressorium generates enormous turgor pressure by accumulating high concentration of compatible solute such as glycerol with the help of melanized cell wall. This pressure is converted into mechanical force, which powers the penetration peg to penetrate the leaf epidermis or stalk cuticle followed by further invasive hyphal expansion to colonize plant tissues (Kankanala et al. 2007; Tufan et al. 2009; Wilson and Talbot 2009). Infection hyphae have cap-like structures known as the biotrophic interfacial complex involved in releasing effectors into the host plant cells (Kankanala et al. 2007; Mosquera et al. 2009; Giraldo et al. 2013). The $M o O$ secrets some effector proteins such as Avr-Pita, Avr-Pii, Avr-Piz-t, Pwl1, ACE1, Bas14, Slp1 and Mc69 that suppress the host immunity through binding chitin oligosaccharides in the apoplast and by targeting multiple components of the host immunity (Mentlak et al. 2012; Liu et al. 2013; Chen et al. 2014). It also secrets antibiotic biosynthesis monooxygenase and the mycotoxin tenuazonic acid, which helps the fungus to colonize in plant tissue for successful biotrophic growth of the fungus (Kankanala et al. 2007; Patkar et al. 2015; Yan and Talbot 2016). The $M o O$ also produces and secretes a diverse array of phytotoxic secondary metabolites to collapse host plants for successful infection (Nukina 1999). However, precise underlying molecular cross-talks between wheat plant and MoT fungus are poorly understood. Disease lesions usually become apparent after $72-96 \mathrm{~h}$ of infection by the conidia (El Refaei 1977; Islam et al. 2016). On the other hand, mycelial mass and spore production are observed after $120 \mathrm{~h}$ of inoculation on plant leaf surface (Ceresini et al. 2018). However, our understanding of the effector biology of $M o T$ is very limited. The infection biology of $M o T$ and its interaction with wheat plants have been elaborately reviewed by Ceresini et al. (2018).

\section{Breeding of resistant wheat cultivars using conventional and advanced genome editing}

Breeding of blast-resistant wheat varieties is an environment-friendly method to control the destructive

Table 2 Comparative status of blast incidence during 2016-2019 in Bangladesh (Data source: BWMRI)

\begin{tabular}{|c|c|c|c|c|}
\hline Events & 2016 & 2017 & 2018 & 2019 \\
\hline Infection time & Mid-February & Mid-January & Early-February & Mid-January \\
\hline Weather condition & $\begin{array}{l}\text { Rain at flowering time } \\
(35 \mathrm{~mm} \text { in Feb.) with } \\
\text { warm temperature } \\
\left(\min .18-23^{\circ} \mathrm{C} \text {, and }\right. \\
\max .21-28^{\circ} \mathrm{C} \text { ) }\end{array}$ & $\begin{array}{l}\text { High humidity due to fog } \\
\text { at flowering and warm } \\
\text { temperature ( } \min .16-18{ }^{\circ} \mathrm{C} \\
\text { and max. } 24-26^{\circ} \mathrm{C} \text { ) }\end{array}$ & $\begin{array}{l}\text { Fluctuation of day-night } \\
\text { temperature (min. } 10-12{ }^{\circ} \mathrm{C} \\
\text { and max. } 26-28^{\circ} \mathrm{C} \text { ) with } \\
\text { high humidity/fog }\end{array}$ & $\begin{array}{l}\text { High humidity due to fog } \\
\text { at flowering and warm } \\
\text { temperature }\left(\min .8-16{ }^{\circ} \mathrm{C}\right. \\
\left.\text { and max. } 24-31^{\circ} \mathrm{C}\right)\end{array}$ \\
\hline Area affected & 15,000 ha (DAE) & 22 ha (DAE) & 15 ha (DAE) & Not estimated \\
\hline Yield losses & $25-30 \%$ & $5-10 \%$ & $1-5 \%$ & $1-5 \%$ \\
\hline Affected districts & $\begin{array}{l}\text { Meherpur, Jhenaidah, } \\
\text { Chuadanga, Jashore, } \\
\text { Pabna, Kushtia, Barisal \& Bhola }\end{array}$ & $\begin{array}{l}\text { Previous districts + } \\
\text { some additional districts: } \\
\text { Faridpur, Rajshahi \& Magura }\end{array}$ & $\begin{array}{l}\text { Previous districts }+ \\
\text { Rajbari, Natore, Tangail \& } \\
\text { Jamalpur }\end{array}$ & $\begin{array}{l}\text { Previous districts + Naogaon, } \\
\text { Mymensingh, Madaripur } \\
\text { \& Narail }\end{array}$ \\
\hline
\end{tabular}


$M o T$ pathogen. Since the first emergence of wheat blast in 1985, an extensive study has been conducted to find out novel resistance sources in wheat germplasms. However, resistance genes or sources in the screened germplasms are still limited. To date, a total of 10 genes and a chromosomal segment have been identified as resistance sources to wheat blast fungus (Table 3). Among them, $R m g 2$ and $R m g 3$ were identified in a common wheat cultivar Thatcher (Zhan et al. 2008), but these genes are ineffective at high temperature or do not express at the heading stage of wheat. The $R m g 7$ gene was identified in an accession of Triticum dicoccum, which is expressed at the heading stage (Tagle et al. 2015). However, this gene did not show efficacy against $M o T$ isolate $\mathrm{Br} 48$ at higher temperature $\left(26^{\circ} \mathrm{C}\right)$ (Anh et al. 2018). Another important gene is $R m g 8$ that was identified by Anh et al. (2015) in common wheat cultivar S-615. Interestingly, $R m g 8$ is expressed at the heading stage and is also effective even at higher temperature $\left(26^{\circ} \mathrm{C}\right)$ (Anh et al. 2018). Field deployment of Rmg8 in blast conducive environment have not yet been done. $R$ gene-mediated immune responses are robust and often lead to host cell death after pathogen infection, limiting resources for pathogen growth (Pieterse et al. 2012; Wang and Valent 2017). Introgression of Rmg8 into local cultivars in Bangladesh and South America might be useful for the development of blast-resistant wheat. The $2 N S$ translocation introduced from Aegilops ventricosa confers resistance to multiple diseases like rusts and powdery mildew, and Cruz et al. (2016b) discovered that it also confers resistance to wheat head blast. Recently, the resistance conferred by $2 N S$ translocation was eroded by a highly aggressive new isolate, B-71, in some wheat genetic backgrounds. Wang et al. (2018) discovered another new resistance gene, $R m g G R 119$, in the common winter wheat accession GR119. In seedling assay, the Rmg8 gene is resistant to Bangladeshi $M o T$ isolate BTJP4-1 but susceptible to Brazilian MoT isolate N06047 (Jensen et al. 2019). These findings are consistent with the observation that AvrRmg8, which encodes the avirulence effector protein recognized by $R m g 8$, is present in Bangladeshi isolates of the wheat blast fungus (Wang et al. 2018). In a similar detached leaf assay, we also found that wheat line GR119 carrying RmgGR119 gene displayed very strong resistance to the $M o T$ isolates in Bangladesh (Islam et al. unpublished). These results are encouraging news for breeding and deployment of resistant wheat varieties with Rmg8 and RmgGR119 in Bangladesh and other South Asian countries. As a preventive measure, Japan has already introduced these genes into their elite wheat varieties (Wang et al. 2018). However, the performances of these genes in protecting wheat from blast fungus in the field conditions have not been tested yet. Discovery of more resistance genes and breeding for resistance to wheat blast are urgent because of the likelihood that wheat blast will spread to other countries in Asia and elsewhere (Wang et al. 2018) in the near future. The biggest challenge in development of wheat blast-resistant cultivars through classical breeding is that it requires longer time (5-10 years) and availability of limited blast-resistant genetic resources. Another important and significant challenge is the high variability in the virulence of the pathogen (Ceresini et al. 2018), which might be considered during development of a resistant wheat variety. In fact, the mechanism of the host plant resistance to wheat blast pathogen is still elusive. Marker-assisted selection (MAS) and speed breeding can expedite the breeding process especially when introgressing major genes. On the other hand, genome editing using CRISPR-Cas technology would be useful for the development of blast-resistant wheat (Haque et al. 2018; Islam 2019). It could be done by either stacking of $R$

Table 3 Resistant genes discovered in wheat and their roles against blast fungus

\begin{tabular}{llll}
\hline Resistant gene & Wheat source & Blast fungal isolate & Reference \\
\hline RmgTd(t) & Triticum dicoccum KU109 (Tat 4) & Not to the field isolate & Takabayashi et al. (2002) \\
Rmg1(Rwt4) & Common wheat, Norin 4 (hexaploid) & Avena isolate Br58 & Takabayashi et al. (2002) \\
Rmg2 & Common wheat, Thatcher & Triticum isolate Br48 & Zhan et al. (2008) \\
Rmg3 & Common wheat, Thatcher & Triticum isolate Br48 & Zhan et al. (2008) \\
Rmg4 & Common wheat, Norin 4 & Digitaria isolate & Nga et al. (2009) \\
Rmg5 & Common wheat, Red Egyptian & Digitaria isolate & Nga et al. (2009) \\
Rmg6(Rwt3) & Common wheat, Norin 4 & Lolium isolate TP2 & Vy et al. (2014) \\
Rmg7 & Triticum dicoccum (tetraploid wheat), & Triticum isolate Br48 & Tagle et al. (2015) \\
Rmg8 & KU112(St17), 120(St24), KU122(St25) & & Anh et al. (2015); Anh et al. (2018) \\
RmgGR119 & Common wheat, S-615 & Triticum isolate Br48 & Wang et al. (2018) \\
2NS translocation & Albanian wheat accession GR119 & Triticum isolate Br48 & Cruz et al. (2016b) \\
\hline
\end{tabular}


genes or deletion or disruption of $S$ genes or transcription factors in the genome of a commercial cultivar (Wang et al. 2016; Nekrasov et al. 2017; Peng et al. 2017; Kim et al. 2019). The latter approach would result in non-transgenic mutated wheat which could be readily released to the practical application without following strict biosafety guidelines (Haque et al. 2018; Langner et al. 2018). As $S$ genes in wheat have not been well characterized, the characterized orthologous $S$ genes in rice could be targeted for identification in wheat for genome editing (Kim et al. 2019). To ease the complication in transformation of wheat, a new targeted mutagenesis in wheat microspores using CRISPR-Cas9 has recently been established (Bhowmik et al. 2018).

As the only confirmed wheat blast-resistant source in field experiments across wide environments, $2 N S$ translocation should also be actively utilized in wheat breeding, especially in countries with wheat blast epidemic. Actually, varieties with $2 N S$ are utilized in many wheat blast-affected countries to cope with the wheat blast infection. Such varieties include CD116 in Brazil, Urubo, INIAF Okinawa and INIAF Tropical in Bolivia, Caninde\#1 in Paraguay, and BARI Gom 33 in Bangladesh. Although $2 N S$ resistance against a new MoT isolate has been eroded, it is still the backbone in wheat blast resistance breeding. New resistance sources, like Rmg8 and RmgGR119, when confirmed in field trials, could be combined with $2 N S$ in breeding to achieve a better resistance. The stacking of $2 N S, R m g 8$ and RmgGR119 is being performed at IBGE of BSMRAU and CIMMYT. In addition to this, some non-2NS lines have been identified as having moderate level of wheat blast resistance under a wide range of environments (Singh PK, unpublished results; Cruppe et al. 2020), and these lines are being crossed with $2 N S$ carriers to pyramid the resistance genes.

\section{Challenges associated with breeding for wheat blast resistance}

Frequency of $2 N S$ translocation in the CIMMYT's germplasm is also affecting breeding for blast resistance. The 2NS-chromosome fragment has already been utilized in cultivars especially in CIMMYT germplasm because of its usefulness against rust. Importantly, it is also reported that all the wheat genotypes having $2 N S$ translocation are not equally effective against wheat blast (Cruz et al. 2016b). Utilization of this translocation should be followed with caution especially the parent selection. Recent international nurseries of CIMMYT evidenced a significant increase in the frequency of $2 N S$ translocation, due to its favorable effects on rust resistance ( $Y r 17$ ) and yield potential (Juliana et al. 2019). Based on last 3 years' research, major and stable QTLs were identified in $2 A S / N S$ translocation region in a biparental population (He et al. 2020). Major effects of $2 A S / N S$ translocation in detecting stable QTLs in Genome Wide Association Analysis (GWAS) was also reported (Juliana et al. 2019). In addition to $2 N S$ translocation, a few non-2NS lines also had consistently low infection, which may indicate the presence of novel resistant gene(s)/QTL in those lines, or recombination happened between the markers for $2 N S$ inference and the resistance gene in $2 N S$ carrying lines.

Synthetic hexaploid wheat (SHW) is an artificially created hexaploid wheat that represents a wider genetic basis because of the introduction of additional genetic resources from tetraploid and diploid relatives of wheat. The SHW has been widely used as a bridge for transferring major disease resistance genes from tetraploid wheat and Aegilops spp. to common wheat. Alien germplasm is an important source of novel genes for wheat improvement. Aegilops umbellulata has been identified as a source of resistance to leaf rust, powdery mildew, Hessian fly, and greenbug (Gill et al. 1985). Synthetic wheat lines are the potential alternatives for non-2NS based resistance given the fact that $2 N S$ has not been utilized in durum breeding. Another fact is that most durum lines tested so far for blast were susceptible; therefore, blast resistance is expected to be from Ae. tauschii. The main bottleneck in using SHW is the extreme difficulties to evaluate those in field condition.

\section{Biological control of the disease using antifungal microorganisms or derivatives}

Biocontrol of plant diseases by using antagonistic microorganisms is a biorational effective strategy against fungal and peronosporomycetal diseases (Islam et al. 2005, 2011; Surovy et al. 2017). Several lines of evidence suggest that some biocontrol agents viz. Bacillus methylotrophicus, Chaetomium globosum and Trichoderma harzianum significantly control rice blast disease (Park et al. 2005; Singh et al. 2012; Oliveira et al. 2015). These antagonistic microorganisms should be tested as agents for seed treatment of suspected contaminated seeds or spray application for wheat blast management. Recently, Dutta et al. (2018) demonstrated that some plant probiotic Bacillus spp. isolated from rice and wheat grains significantly controlled wheat blast disease in the greenhouse and field conditions in Bangladesh (Islam et al. unpublished). Genomic and laboratory analyses revealed that these bacteria suppressed wheat blast fungus through antibiosis and induced systemic resistance in the wheat plants. Recently, Chakraborty et al. (2020) demonstrated that some non-cytotoxic linear lipopeptide isolated from a marine Bacillus subtilis strain 109GGC020 inhibited asexual development (inhibited conidiogenesis and germination of conidia) of the MoT fungus both in vitro and in vivo. Among the 5 
compounds identified, gageotetrin B displayed the highest mycelial growth inhibition of $M o T$ followed by gageopeptide $\mathrm{C}$, gageopeptide $\mathrm{D}$, gageopeptide $\mathrm{A}$ and gageopeptide $\mathrm{B}$ with minimum inhibitory concentrations (MICs) of 1.5, 2.5, 2.5, 10.0 and $10.0 \mu \mathrm{g} /$ disk, respectively. Application of these natural compounds have also completely blocked formation of conidia in the $M o T$ fungal mycelia in the agar medium. Further bioassay revealed that these natural compounds inhibited the germination of $M o T$ conidia, and even if conidia germinated, induced deformation of germ tube and/or abnormal appressoria occurred (Chakraborty et al. 2020). Application of these linear lipopeptides significantly suppressed wheat blast disease on detached wheat leaves. Further studies are needed to elucidate the mode of action and practical application of these natural agents in controlling head blast in the field conditions.

\section{Globally concerted effort to control the seed- and air- borne wheat blast}

A concerted and well-coordinated global effort is needed to address this potentially catastrophic plant disease. To manage the problem of wheat blast disease, a concerted effort under following directions should be considered: (i) increase awareness of the risk of outbreak of wheat blast in wheat-growing countries, and improve understanding of factors related to potential emergence; (ii) strengthen quarantine and biosafety regulations in disease-free countries, and appropriate phytosanitary measures and certification should be followed to import seeds/grains from blast affected countries; (iii) develop a convenient diagnostic tool for early detection of seedborne inoculum, monitoring and surveillance of wheat blast; (iv) forecast and monitor infection periods based on weather conditions; (v) discover novel chemical and biocontrol alternatives for managing wheat blast; (vi) monitor MoT populations to track the evolution (virulence/fungicide resistance) of the pathogen in South America and Bangladesh; (vii) increase the availability of innovative solutions (e.g. biocontrol products and integrated disease management strategies) to reduce yield losses due to wheat blast; (viii) develop durable blast-resistant wheat varieties using classical and frontier technologies such as CRISPR-Cas genome editing. It is advisable to take initiatives for lab capacity improvement, personnel training, and information sharing by the wheat-growing countries. Open science and open data sharing approaches are needed to rapidly tackle this destructive wheat killer through the engagement of global scientific, political and social communities as used by Open Wheat Blast community (http://openwheatblast.net).
Challenge and opportunity in wheat blast management The most important challenge with $M o T$ fungus is insufficient knowledge on its biology and host-pathogen interactions. Little is known on molecular cross-talks between $M o T$ and its host wheat plant. The pathogen is fast evolving in the natural environment, and more than 200 genetic variants have been identified in South America (Ceresini et al. 2018). One of the major problems associated with wheat blast is that it infects the rachis, resulting in partial or total bleaching of the spikes. All the spikelets above the point of infection become bleached. Development of resistance to fungicides in $M o T$ fungus is another important challenge although the efficacy of fungicides after the expression of the spike blast symptoms is very poor (Castroagudin et al. 2015). Most of the $R$ genes (Rmg $1-7)$ are ineffective at higher temperature and/or in field deployment (Cruz and Valent 2017). Although $2 N S$ translocation containing varieties show moderate to high resistance to most of the isolates of wheat blast fungus, a few highly virulent isolates (e.g. B71) eroded this resistance. Resistance sources ( $R$-genes) useful for breeding of blast-resistant wheat variety are limited. However, a few non-2NS translocation have also been found in wheat breeding for blast resistance. Precision phenotyping platforms for wheat blast in Bangladesh, and Bolivia need to be strengthened to increase the efficiency of discovery of novel sources of resistance. Two newly discovered wheat blast resistance genes, Rmg8 and RmgGR119, have potentials for resisting the $M o T$ fungus attack, however, they were not yet deployed in the hot spots of the wheat blast in Bangladesh (Meherpur) or South American countries. Breeding for development of blast-resistant wheat variety through backcrossing with germplasms carrying $2 N S$ translocation, $R m g 8$ and $R m g G R 119$ are needed. A good number of $R$ genes of rice have been cloned for blast resistance that may also be screened for wheat blast resistance. However, transformation of wheat is complicated due to hexaploidy and thus development of novel convenient methods for wheat transformation need to be developed. The new technology, CRISPR-Cas genome editing seems more suitable for development of new blast-resistant wheat variety either by stacking $R$-genes or mutagenesis of the $S$ genes. Integrated management strategies need to be employed for management of the fearsome wheat blast. A convenient, cost-effective, specific and rapid diagnostic tools need to be developed for monitoring and surveillance of the $M o T$ pathogen. From the analyses of epidemiological factors, it appears that major wheat-growing countries in the world such as eastern and southern India, northern China, south-eastern USA and southern Europe are vulnerable to wheat blast. The recent and dramatic outbreak of wheat blast in Bangladesh exemplifies the risk 
of introduction through seeds or grains. The second risk is a host jump from cultivated or wild Lolium to wheat.

\section{Future directions and perspectives}

Wheat blast is a destructive fungal disease, which poses a serious threat to wheat production in the affected countries in South America and Bangladesh. Its recent introduction to Bangladesh, and the seed- and air-borne nature of the fungus are major risk factors of its spread to the neighboring major wheat-growing countries in Asia. Development of a convenient diagnostic tool is needed for monitoring and the surveillance of this invasive fungus. It is advisable to include this intervention in the global efforts including lab capacity improvement, personnel training, and information sharing. Another important target is the development of durable blast resistant varieties using classical or modern breeding technology such as CRISPR-Cas gene editing technology. To address other challenges mentioned in earlier sections, some strategic efforts and research on public awareness, plant and pathogen perspectives, and biological and chemical efforts are needed on an urgent basis (please see details in Table 4). Furthermore, a global concerted research effort is needed to mitigate the wheat blast with practicing of open science and open data sharing (Kamoun et al. 2019).

\section{Conclusions}

The destructive wheat blast disease, caused by the fungus M. oryzae Triticum lineage, is a threat to wheat production in South America and Bangladesh. This review updated our understanding about the wheat blast disease and discussed potential approaches for its mitigation. Major world's wheat-growing countries of the world are free from wheat blast disease. As this fungal pathogen is invasive, highly evolving and potentially catastrophic in various agro-ecological zones, a globally concerted effort is needed to prevent its inadvertent introduction and spread. First, basic research is needed to understand the biology of the fungus and its molecular cross-talks with host plant. Second, a rapid, convenient and specific diagnostic tool is needed for early detection of seed-borne inoculum, monitoring and surveillance of the wheat blast. Third, globally available wheat germplasms are needed to be screened in the hotspots of wheat blast in Bangladesh and South America to discover novel resistance sources. Fourth, development of durable and locally adaptable blast-resistant varieties is needed by the deployment of newly discovered $R$-genes using MAS, speed breeding and CRISPR-Cas genome editing technology.

Table 4 Future directions towards the management of wheat blast disease

\begin{tabular}{|c|c|}
\hline Strategy & Proposed action \\
\hline Public awareness & $\begin{array}{l}\text { a) A concerted global effort to increase awareness of the plight of the challenge in feeding the increasing global } \\
\text { population. } \\
\text { b) More effort to enhance awareness of the need for international cooperation and philanthropy to fund strategies that } \\
\text { boost wheat production and protect the crop from worrisome blast disease. } \\
\text { c) Strictly follow the rules and regulations of quarantine during global trading of wheat seeds/grains. }\end{array}$ \\
\hline Plant perspective & $\begin{array}{l}\text { a) More research is needed to find out new resistance sources and discover novel durable broad-spectrum resistant genes } \\
\text { from wheat genetic resources. } \\
\text { b) More research is needed to elucidate molecular cross-talks between wheat plant and blast fungus for the development } \\
\text { of a management strategy against the disease. } \\
\text { c) An international cooperative research program is needed to systematically pyramid resistance genes in local elite } \\
\text { cultivars. } \\
\text { d) Develop convenient methods for transformation of wheat varieties. } \\
\text { e) Breeding program for the deployment of available } R \text { genes and mutagenesis of } S \text { genes by using CRISPR-Cas } \\
\text { technology. }\end{array}$ \\
\hline Pathogen perspective & $\begin{array}{l}\text { a) Effort to start an integrated international research to monitor the genetic composition and virulence diversity of blast } \\
\text { populations in Bangladesh and South America over time and space. } \\
\text { b) Develop convenient diagnostic tools for monitoring and surveillance of the pathogen. } \\
\text { c) Develop infection assays that identify all blast avirulence genes across an extended and universally applicable repertoire } \\
\text { of differential wheat cultivars. }\end{array}$ \\
\hline $\begin{array}{l}\text { Biological and chemical } \\
\text { control }\end{array}$ & $\begin{array}{l}\text { a) Develop elite strains of biocontrol agents from the native environments through extensive screening. } \\
\text { b) Disease control to be assessed in field trials and not in laboratory or in restricted glasshouse tests. } \\
\text { c) Evaluation and continuous monitoring of the virulence status of introduced biocontrol agents. } \\
\text { d) Assessment of biocontrol agent efficacy under different environments. } \\
\text { e) Extensive research effort to find new broad-spectrum, low-dose-rate and low-ecological-impact fungicides via the ra- } \\
\text { tional design of target-site-specific antifungals. } \\
\text { f) Discovery of new plant activator chemistries but with appropriate evaluation of their effect on wheat growth and crop } \\
\text { yield. } \\
\text { g) Genome-wide screening for wheat genes encoding antifungal proteins. } \\
\text { h) Field evaluation of transgenics in disease control and durability. }\end{array}$ \\
\hline
\end{tabular}


Fifth, discover and develop innovative solutions (e.g. biocontrol products and integrated disease management strategies) to reduce yield losses due to wheat blast. To accelerate the speed of research, open science and open data sharing approaches should be practiced in addressing the potential impact of this destructive wheat killer.

\begin{abstract}
Abbreviations
BARI: Bangladesh Agricultural Research Institute; BSMRAU: Bangabandhu Sheikh Mujibur Rahman Agricultural University; BWMRI: Bangladesh Wheat and Maize Research Institute; Cas: CRISPR-associated; CIMMYT: Centro Internacional de Mejoramiento de Maíz y Trigo or International Maize and Wheat Improvement Center; CRISPR: Clustered Regularly Interspaced Short Palindromic Repeats; DAE: Department of Agricultural Extension; FAO: Food and Agriculture Organization; FHB: Fusarium head blight; IBGE: Institute of Biotechnology and Genetic Engineering; MoT: Magnaporthe oryzae Triticum; PCR: Polymerase Chain Reaction; QTL: Quantitative Trait Locus
\end{abstract}

\section{Acknowledgements}

The authors are thankful to Md Shabab Mehebub of Institute of Biotechnology and Genetic Engineering of BSMRAU for the assistance of some images used in Fig. 1.

\section{Authors' contributions}

MTI conceived the idea and drafted the manuscript; DRG, AH, KKR, XH, MRK drafted the manuscript; PKS, MARK, MR, and GLW edited and revised the manuscript. All authors read and approved the final manuscript.

\section{Funding}

This work was supported by grants from the Krishi Gobeshona Foundation (KGF), Bangladesh project No. TF50-C/17 and the IAEA/FAO. The wheat blast research in GLW's laboratory is supported by the Coordinated Research Program of the International Atomic Energy Agency (IAEA) and the SEEDS program, OARDC, the Ohio State University.

\section{Availability of data and materials}

Not applicable.

\section{Ethics approval and consent to participate}

Not applicable.

\section{Consent for publication}

Not applicable.

\section{Competing interests}

The authors declare that they have no competing interests.

\section{Author details}

${ }^{1}$ Institute of Biotechnology and Genetic Engineering (IBGE), Bangabandhu Sheikh Mujibur Rahman Agricultural University, Gazipur 1706, Bangladesh. ${ }^{2}$ Bangladesh Wheat and Maize Research Institute (BWMRI), Dinajpur 5200, Bangladesh. ${ }^{3}$ International Maize and Wheat Improvement Center (CIMMYT), Apdo, Postal 6-641, 06600 Mexico DF, Mexico. ${ }^{4}$ Department of Agronomy, Bangabandhu Sheikh Mujibur Rahman Agricultural University, Gazipur 1706, Bangladesh. ${ }^{5}$ West Virginia University, Morgantown, USA. ${ }^{6}$ Department of Plant Pathology, Ohio State University, Columbus, OH 43210, USA.

Received: 19 May 2020 Accepted: 5 August 2020

Published online: 03 September 2020

\section{References}

Anh VL, Anh NT, Tagle AG, Vy TT, Inoue Y, Takumi S, et al. Rmg8, a new gene for resistance to Triticum isolates of Pyricularia oryzae in hexaploid wheat. Phytopathology. 2015;105(12):1568-72.

Anh VL, Inoue Y, Asuke S, Vy TTP, Anh NT, Wang S, et al. Rmg8 and Rmg7, wheat genes for resistance to the wheat blast fungus, recognize the same avirulence gene AVR-Rmg8. Mol Plant Pathol. 2018;19:1252-6.

Barea G, Toledo J. Identificación y zonificación de Pyricularia o brusone (Pyricularia oryzae) en el cutivo de trigo en el departamento de Santa Cruz.
Santa Cruz de la Sierra: Centro de Investigación Agrícola Tropical. Informe Tecnico. Proyecto de Investigacion Trigo; 1996. p. 76-86.

Bhowmik P, Ellison E, Polley B, Bollina V, Kulkarni M, Ghanbarnia K, et al. Targeted mutagenesis in wheat microspores using CRISPR/Cas9. Sci Rep. 2018;8:6502.

Cabrera MG, Gutiérrez S. Primer registro de Pyricularia grisea en cultivos de trigo del NE de Argentina. Jornada de Actualización en Enfermedades de Trigo. Buenos Aires: IFSC Press; 2007;60.

Callaway E. Devastating wheat fungus appears in Asia for first time. Nature. 2016; 532:421-2.

Castroagudin VL, Ceresini PC, de Oliveira SC, Reges JTA, Maciel JLN, Bonato ALN, et al. Resistance to Qol fungicides is widespread in Brazilian populations of the wheat blast pathogen Magnaporthe oryzae. Phytopathology. 2015;105: 284-94.

Cardoso CAA, Reis EM, Moreira EN. Development of a warning system for wheat blast caused by Pyricularia grisea. Summa Phytopathol. 2008;34:216-21.

Ceresini PC, Castroagudín VL, Rodrigues FA, Rios JA, Aucique-Pérez CE, Moreira SI, et al. Wheat blast: past, present, and future. Annu Rev Phytopathol. 2018;56: $427-56$.

Ceresini PC, Castroagudín VL, Rodrigues FA, Rios JA, Aucique-Pérez CE, Moreira SI, et al. Wheat blast: from its origins in South America to its emergence as a global threat. Mol Plant Pathol. 2019;20(2):155-72.

Chakraborty M, Mahmud NU, Gupta DR, Tareq FS, Shin HJ, Islam T. Inhibitory effects of linear lipopeptides from a marine Bacillus subtilis on the wheat blast fungus Magnaporthe oryzae Triticum. Front Microbiol. 2020;11:665.

Chen XL, Shi T, Yang J, Shi W, Gao X, Chen D, et al. N-glycosylation of effector proteins by an $a-1,3$-mannosyltransferase is required for the rice blast fungus to evade host innate immunity. Plant Cell. 2014;26(3): 1360-76.

Chiapello H, Mallet L, Guérin C, Aguileta G, Amselem J, Kroj T, et al. Deciphering genome content and evolutionary relationships of isolates from the fungus Magnaporthe oryzae attacking different host plants. Genome Biol Evol. 2015; 7:2896-912.

Cruppe G, Cruz CD, Peterson G, Pedley K, Asif M, Fritz A, et al. Novel sources of wheat head blast resistance in modern breeding lines and wheat wild relatives. Plant Dis. 2020;104:35-43.

Cruz CD, Kiyuna J, Bockus WW, Todd TC, Stack JP, Valent B. Magnaporthe oryzae conidia on basal wheat leaves as a potential source of wheat blast inoculum. Plant Pathol. 2015;64(6):1491-8.

Cruz CD, Magarey RD, Christie DN, Fowler GA, Fernandes JM, Bockus WW, et al. Climate suitability for Magnaporthe oryzae Triticum pathotype in the United States. Plant Dis. 2016b;100:1979-87.

Cruz CD, Peterson GL, Bockus WW, Kankanala P, Dubcovsky J, Jordan KW, et al. The 2NS translocation from Aegilops ventricosa confers resistance to the Triticum pathotype of Magnaporthe onyzae. Crop Sci. 2016a;56(3):990-1000.

Cruz CD, Valent B. Wheat blast disease: danger on the move. Trop Plant Pathol. 2017:42:210-22.

Dutta S, Surovy MZ, Gupta DR, Mahmud NU, Chanclud E, Win J, et al. Genomic analyses reveal that biocontrol of wheat blast by Bacillus spp. may be linked with production of antimicrobial compounds and induced systemic resistance in host plants. Figshare. 2018;17:48.

Duveiller E, Hodson D, Sonder K, von Tiedemann A. An international perspective on wheat blast. Phytopathology. 2011;101:S220.

El Refaei MI. Epidemiology of rice blast disease in tropics with special reference to the leaf wetness in relation to disease development. New Delhi: Ph.D. Thesis, Indian Agricultural Research Institute; 1977.

Faivre-Rampant O, Thomas J, Allegre M, Morel JB, Tharreau D, Notteghem JL, et al. Characterization of the model system rice-Magnaporthe for the study of non-host resistance in cereals. New Phytol. 2008;180:899-910.

Farman M, Peterson G, Chen L, Starnes J, Valent B, Bachi P, et al. The Lolium pathotype of Magnaporthe oryzae recovered from a single blasted wheat plant in the United States. Plant Dis. 2017;101:684-92.

Farman ML. Pyricularia grisea isolates causing gray leaf spot on perennial ryegrass (Lolium perenne) in the United States: relationship to P. grisea isolates from other host plants. Phytopathol. 2002;92:245-54.

Fernández-Ortuño D, Pérez-García A, López-Ruiz F, Romero D, de Vicente A, Torés $J A$. Occurrence and distribution of resistance to Qol fungicides in populations of Podosphaera fusca in south Central Spain. Eur J Plant Pathol. 2006;115:215-22.

Fisher MC, Henk DA, Briggs CJ, Brownstein JS, Madoff LC, McCraw SL, et al. Emerging fungal threats to animal, plant and ecosystem health. Nature. 2012; 484:186-94. 
Gill BS, Sharma HC, Raupp WJ, Browder LE, Hatchett JH, Harvely TL, et al. Evaluation of Aegilops species for resistance to wheat powdery mildew, wheat leaf rust, Hessian fly and green bug. Plant Dis. 1985;69:314-6.

Giraldo MC, Dagdas YF, Gupta YK, Mentlak TA, Yi M, Martinez-Rocha AL, et al. Two distinct secretion systems facilitate tissue invasion by the rice blast fungus Magnaporthe oryzae. Nat Commun. 2013:4:1996.

Gladieux P, Condon B, Ravel S, Soanes D, Maciel JL, Nhani A, et al. Gene flow between divergent cereal- and grass-specific lineages of the rice blast fungus Magnaporthe oryzae. mBio. 2018;9:001219-7.

Goulart ACP, Paiva FA, Mesquita AN. Occurrence of wheat blast (Pyricularia oryzae) in the state of Mato Grosso do Sul. Fitopatol Bras. 1990;15:112-4 (in Portuguese).

Goulart ACP, Paiva FA. Incidence of blast (Pyricularia oryzae) in different wheat cultivars under field conditions. Fitopatol Bras. 1992;17:321-5 (in Portuguese).

Goulart ACP, Paiva FA. Wheat yield losses due to Pyricularia grisea, in 1991 and 1992, in the state of Mato Grosso do Sul. Summa Phytopathol. 2000;26(2): 279-82 (in Portuguese).

Goulart ACP, Paiva FA, Mesquita N. Perdas em trigo (Triticum aestivum) causadas por Pyricularia oryzae. Fitopatol Bras. 1992;17:115-7 (in Portuguese).

Goulart ACP, Sousa PG, Urashima AS. Damages in wheat caused by infection of Pyricularia grisea. Summa Phytopathol. 2007;33:358-63.

Gupta DR, Avila CS, Win J, Soanes DM, Ryder LS, Croll D, et al. Cautionary notes on use of the MoT3 diagnostic assay for Magnaporthe oryzae wheat and rice blast isolates. Phytopathol. 2019;109:504-8.

Ha X, Wei T, Koopmann B, von Tiedemann A. Microclimatic requirements for wheat blast (Magnaporthe grisea) and characterisation of resistance in wheat. In: Tielkes $E$, editor. Resilience of agricultural systems against crises. Göttingen: Cuvillier Verlag; 2012. p. 155.

Hamer JE, Howard RJ, Chumley FG, Valent B. A mechanism for surface attachment in spores of a plant pathogenic fungus. Science. 1988;239(4837): 288-90.

Haque E, Taniguchi H, Hassan MM, Bhowmik P, Karim MR, Śmiech M, et al. Application of CRISPR/Cas9 genome editing technology for the improvement of crops cultivated in tropical climates: recent progress, prospects, and challenges. Front Plant Sci. 2018;9:617.

He X, Kabir MR, Roy KK, Anwar MB, Xu K, Marza F, et al. QTL mapping for field resistance to wheat blast in the Caninde\#1/Alondra population. Theor Appl Genet. 2020. https://doi.org/10.1007/s00122-020-03624-x.

Hossain A, da Silva JAT. Wheat production in Bangladesh: its future in the light of global warming. AoB Plants. 2013;5:pls042.

Igarashi S. Update on wheat blast (Pyricularia oryzae) in Brazil. In: Saunders DA, editor. A proceeding of the international conference-wheat for the nontraditional warm areas. Mexico: CIMMYT; 1990. p. 480-3.

Igarashi S, Utiamada CM, Igarashi LC, Kazuma AH, Lopes RS. Occurrence of Pyrcularia sp. in wheat (Triticum aestivum L.) in the state of Paraná, Brazil. Fitopatol Bras. 1986:11:351-2.

Inoue Y, Vy TTP, Yoshida K, Asano H, Mitsuoka C, Asuke S, et al. Evolution of the wheat blast fungus through functional losses in a host specificity determinant. Science. 2017;357(6346):80-3.

Islam MT, Croll D, Gladieux P, Soanes DM, Persoons A, Bhattacharjee P, et al. Emergence of wheat blast in Bangladesh was caused by a south American lineage of Magnaporthe oryzae. BMC Biol. 2016;14:84.

Islam MT, Hashidoko Y, Deora A, Ito T, Tahara S. Suppression of damping-off disease in host plants by the rhizoplane bacterium Lysobacter sp. strain SBK88 is linked to plant colonization and antibiosis against soil-borne Peronosporomycetes. Appl Environ Microbiol. 2005;71:3786-96.

Islam MT, Kim KH, Choi J. Wheat blast in Bangladesh: the current situation and future impacts. Plant Pathol J. 2019;35(1):1-10.

Islam MT, von Tiedemann A, Laatsch H. Protein kinase C is likely to be involved in zoosporogenesis and maintenance of flagellar motility in the peronosporomycete zoospores. Mol Plant-Microbe Interact. 2011;24(8): 938-47.

Islam T. CRISPR-Cas technology in modifying food crops. CAB Rev. 2019;14:50. https://doi.org/10.1079/PAVSNNR201914050.

Jensen C, Tosa Y, Islam MT, Talbot NJ, Kamoun S, Saunders DGO. Rmg8 confers resistance to the Bangladeshi lineage of the wheat blast fungus. Zenodo. 2019. https://doi.org/10.5281/zenodo.2574196.

Juliana P, Poland J, Huerta-Espino J, Shrestha S, Crossa J, Crespo-Herrera L, et al. Improving grain yield, stress-resilience, and quality of bread wheat using large-scale genomics. Nat Genet. 2019;51:1530-9.
Kamoun S, Talbot NJ, Islam MT. Plant health emergencies demand open science: tackling a cereal killer on the run. PLOS Biol. 2019:17:e3000302.

Kankanala P, Czymmek K, Valent B. Roles for rice membrane dynamics and plasmodesmata during biotrophic invasion by the blast fungus. Plant Cell. 2007;19:706-24.

Kato H, Yamamoto M, Yamaguchi-Ozaki T, Kadouchi H, Iwamoto Y, Nakayashiki H, et al. Pathogenicity, mating ability and DNA restriction fragment length polymorphisms of Pyricularia populations isolated from Gramineae, Bambusideae and Zingiberaceae plants. J Gen Plant Pathol. 2000;66:30-47.

Kim YA, Moon H, Park CJ. CRISPR/Cas9-targeted mutagenesis of Os8N3 in rice to confer resistance to Xanthomonas oryzae pv. oryzae. Rice. 2019;12:67.

Kohli MM, Mehta YR, Guzman E, De Viedma L, Cubilla LE. Pyricularia blast - a threat to wheat cultivation. Czech J Genet Plant Breed. 2011;47:S130-4.

Langner T, Kamoun S, Belhaj K. CRISPR crops: plant genome editing toward disease resistance. Annu Rev Phytopathol. 2018;56:479-512.

Liu W, Liu J, Ning Y, Ding B, Wang X, Wang Z, et al. Recent progress in understanding PAMP-and effector-triggered immunity against the rice blast fungus Magnaporthe oryzae. Mol Plant. 2013;6(3):605-20.

Maciel JLN, Ceresini PC, Castroagudin VL, Zala M, Kema GHJ, McDonald BA. Population structure and pathotype diversity of the wheat blast pathogen Magnaporthe oryzae 25 years after its emergence in Brazil. Phytopathology. 2014;104:95-107. https://doi.org/10.1094/PHYTO-11-12-0294-R.

Maekawa T, Schulze-Lefert P. Caught in the jump. Science. 2017;357(6346):31-2.

Malaker PK, Barma NCD, Tiwari TP, Collis WJ, Duveiller E, Singh PK, et al. First report of wheat blast caused by Magnaporthe oryzae pathotype Triticum in Bangladesh. Plant Dis. 2016;100:2330.

McGrath MT. Fungicide resistance in cucurbit powdery mildew: experience and challenges. Plant Dis. 2001;85:236-45.

Mentlak TA, Kombrink A, Shinya T, Ryder LS, Otomo I, Saitoh H, et al. Effectormediated suppression of chitin-triggered immunity by Magnaporthe oryzae is necessary for rice blast disease. Plant Cell. 2012;24:322-35.

Mosquera G, Giraldo MC, Khang CH, Coughlan S, Valent B. Interaction transcriptome analysis identies Magnaporthe oryzae BAS1-4 as biotrophyassociated secreted proteins in rice blast disease. Plant Cell. 2009;21: 1273-90.

Mottaleb KA, Singh PK, Sonder K, Kruseman G, Tiwari TP, Barma NCD, et al. Threat of wheat blast to South Asia's food security: an ex-ante analysis. PLoS One. 2018;13:e0197555.

Nekrasov V, Wang C, Win J, Lanz C, Weigel D, Kamoun S. Rapid generation of a transgene free powdery mildew resistant tomato by genome deletion. Sci Rep. 2017;7:482.

Nga NTT, Hau VTB, Tosa Y. Identification of genes for resistance to a Digitaria isolate of Magnaporthe grisea in common wheat cultivars. Genome. 2009;52: 801-9.

Nukina M. The blast disease fungi and their metabolic products. J Pestic Sci. 1999;24:293-8. (in Japanese). https://doi.org/10.1584/jpestics.24.293.

Oliveira SC, Castroagudín VL, Nunes Maciel JL, dos Santos Pereira DA, Ceresini PC. Cross-resistance to Qol fungicides azoxystrobin and pyraclostrobin in the wheat blast pathogen Pyricularia oryzae in Brazil. Summa Phytopathol. 2015; 41(4):298-304 (in Portuguese).

Park JH, Choi GJ, Jang KS, Lim HK, Kim HT, Cho KY, et al. Antifungal activity against plant pathogenic fungi of chaetoviridins isolated from Chaetomium globosum. FEMS Microbiol Lett. 2005;252(2):309-13.

Patkar RN, Benke PI, Qu Z, Chen YY, Yang F, Swarup S, et al. A fungal monooxygenase-derived jasmonate attenuates host innate immunity. Nat Chem Biol. 2015;11:733-40.

Peng AH, Chen SC, Lei TG, Xu LZ, He YR, Wu L, et al. Engineering canker-resistant plants through CRISPR/Cas9-targeted editing of the susceptibility gene CSLOB1 promoter in citrus. Plant Biotechnol J. 2017;15:1509-19.

Pieck ML, Ruck A, Farman ML, Peterson GL, Stack JP, Valent B, et al. Genomicsbased marker discovery and diagnostic assay development for wheat blast. Plant Dis. 2017;101(1):103-9.

Pieterse CMJ, Van der Does D, Zamioudis C, Leon-Reyes A, Van Wees SCM. Hormonal modulation of plant immunity. Annu Rev Cell Dev Biol. 2012;28: 489-521.

Pizolotto CA, Maciel JLN, Fernandes JMC, Boller W. Saprotrophic survival of Magnaporthe oryzae in infested wheat residues. Eur J Plant Pathol. 2019;153: 327-39.

Prabhu AS, Filippi MC, Castro N. Pathogenic variation among isolates of Pyricularia oryzae affecting rice, wheat and grasses in Brazil. Trop Pest Manage. 1992;38:367-71. 
Scheben A, Edwards D. Genome editors take on crops. Science. 2017;355(6330): $1122-3$.

Singh PK, Singh AK, Singh HB, Dhakad BK. Biological control of rice blast disease with Trichoderma harzianum in direct seeded rice under medium low land rainfed conditions. Environ Ecol. 2012;30(3B):834-7.

Surovy MZ, Gupta DR, Chanclud E, Win J, Kamoun S, Islam T. Plant probiotic bacteria suppress wheat blast fungus Magnaporthe oryzae Triticum pathotype. Figshare. 2017. https://doi.org/10.6084/m9.figshare.5549278.v1.

Surovy MZ, Gupta DR, Mahmud NU, Bhattacharjee P, Hossain MS, Mehebub MS, Rahaman $\mathrm{M}$, et al. Modulation of nutritional and biochemical properties of wheat grains infected by the blast fungus Magnaporthe oryzae Triticum pathotype. Front Microbiol. 2020. https://doi.org/10.3389/fmicb.2020.01174.

Tagle AG, Chuma I, Tosa Y. Rmg7, a new gene for resistance to Triticum isolates of Pyricularia oryzae identified in tetraploid wheat. Phytopathology. 2015;105: 495-9.

Takabayashi N, Tosa Y, Oh HS, Mayama S. A gene-for-gene relationship underlying the species-specific parasitism of Avena/Triticum isolates of Magnaporthe grisea on wheat cultivars. Phytopathology. 2002;92(11):1182-8.

Thierry M, Gladieux P, Fournier E, Tharreau D, loos R. A genomic approach to develop a new GPCR test enabling detection of the Pyricularia oryzae lineage causing wheat blast. Plant Dis. 2020;104:60-70.

Tosa Y, Tamba H, Tanaka K, Mayama S. Genetic analysis of host species specificity of Magnaporthe oryzae isolates from rice and wheat. Phytopathology. 2006; 96(5):480-4.

Tufan HA, McGrann GRD, Magusin A, Morel JB, Miché L, Boyd LA. Wheat blast: histopathology and transcriptome reprogramming in response to adapted and non-adapted Magnaporthe isolates. New Phytol. 2009;184:473-84.

Urashima AS. Blast. In: Bockus WW, Bowden RL, Hunger RM, Morrill WL, Murray TD, Smiley RW, editors. Compendium of wheat diseases and pests. 3rd ed. Saint Paul: American Phytopathological Society Press; 2010. p. 22-3.

Urashima AS, Grosso CRF, Stabili A, Freitas EG, Silva CP, Netto DCS, et al. Effect of Magnaporthe grisea on seed germination, yield and quality of wheat. In: Advances in genetics, genomics and control of Rice blast disease. Dordrecht: Springer; 2009. p. 267-77.

Urashima AS, Hashimoto Y, Don LD, Kusaba M, Tosa Y, Nakayashiki H, et al. Molecular analysis of the wheat blast population in Brazil with a homolog of retrotransposon MGR583. Ann Phytopathol Soc Jpn. 1999;65:429-36.

Urashima AS, Igarashi S, Kato H. Host range, mating type, and fertility of Pyricularia grisea from wheat in Brazil. Plant Dis. 1993;77:1211-6.

Urashima AS, Martins TD, Bueno CRNC, Favaro DB, Arruda MA, Mehta YR. Triticale and barley: new hosts of Magnaporthe grisea in São Paulo, Brazil-relationship with blast of rice and wheat. In: Kawasaki S, editor. Rice blast: interaction with Rice and control. Dordrecht: Springer; 2004. p. 251-60.

Valent B, Farman M, Tosa Y, Begerow D, Fournier E, Gladieux P, et al. Pyricularia graminis-tritici is not the correct species name for the wheat blast fungus: response to Ceresini et al. (MPP 20: 2). Mol Plant Pathol. 2019;20:173-9.

Vales M, Anzoátegui T, Huallpa B, Cazon Ml. Review on resistance to wheat blast disease (Magnaporthe oryzae Triticum) from the breeder point-of-view: use of the experience on resistance to rice blast disease. Euphytica. 2018;214:1. https://doi.org/10.1007/s10681-017-2087-x.

Viedma LQ, Morel W. Añublo o Piricularia del Trigo (Wheat Blast). Díptico. MAG/ DIA/CRIA. Programa de Investigación de Trigo. Paraguay: CRIA; 2002.

Vy TTP, Hyon GS, Nga NTT, Inoue Y, Chuma I, Tosa Y. Genetic analysis of hostpathogen incompatibility between Lolium isolates of Pyricularia oryzae and wheat. J Gen Plant Pathol. 2014;80:59-65.

Wang F, Wang C, Liu P, Lei C, Hao W, Gao Y, et al. Enhanced rice blast resistance by CRISPR/Cas9-targeted mutagenesis of the ERF transcription factor gene OsERF922. PLOS One. 2016;11(4):e0154027.

Wang GL, Valent B. Durable resistance to rice blast. Science. 2017;355(6328): 906-7.

Wang S, Asuke S, Vy TTP, Inoue Y, Chuma I, Win J, et al. A new resistance gene in combination with Rmg8 confers strong resistance against Triticum isolates of Pyricularia oryzae in a common wheat landrace. Phytopathology. 2018;108: 1299-306.

Wilson RA, Talbot NJ. Under pressure: investigating the biology of plant infection by Magnaporthe oryzae. Nat Rev Microbiol. 2009;7(3):185-95.

Yan X, Talbot NJ. Investigating the cell biology of plant infection by the rice blast fungus Magnaporthe oryzae. Curr Opin Microbiol. 2016;34:147-53.

Yasuhara-Bell J, Pedley KF, Farman M, Valent B, Stack JP. Specific detection of the wheat blast pathogen (Magnaporthe onzzae Triticum) by loop-mediated isothermal amplification. Plant Dis. 2018;102:2550-9.
Yoshida K, Saunders DGO, Mitsuoka C, Natsume S, Kosugi S, Saitoh H, et al. Host specialization of the blast fungus Magnaporthe oryzae is associated with dynamic gain and loss of genes linked to transposable elements. BMC Genomics. 2016;17:370.

Zaidi SS-A, Mukhtar MS, Mansoor S. Genome editing: targeting susceptibility genes for plant disease resistance. Trends Biotechnol. 2018;36(9):898-906

Zhan SW, Mayama S, Tosa Y. Identification of two genes for resistance to Triticum isolates of Magnaporthe oryzae in wheat. Genome. 2008;51:216-21.
Ready to submit your research? Choose BMC and benefit from:

- fast, convenient online submission

- thorough peer review by experienced researchers in your field

- rapid publication on acceptance

- support for research data, including large and complex data types

- gold Open Access which fosters wider collaboration and increased citations

- maximum visibility for your research: over $100 \mathrm{M}$ website views per year

At $\mathrm{BMC}$, research is always in progress.

Learn more biomedcentral.com/submissions 